\title{
Os desafios linguístico-cognitivos na tarefa da interpretação vocalizada da Libras para língua portuguesa no contexto educacional
}

\author{
The linguistic-cognitive challenges in the task of vocalized \\ interpretation of Libras for Portuguese Language in the educational \\ context
}

\author{
Flávia Medeiros Álvaro Machado ${ }^{1}$ \\ Leandro Alves Wanzeler ${ }^{2}$ \\ Rutileia Gusmão Pinheiro ${ }^{3}$
}

\begin{abstract}
Resumo: O artigo tem por objetivo analisar e investigar as competências linguísticas que o tradutor e intérprete de língua portuguesa/Libras - TILSP precisa obter durante a interpretação simultânea vocalizada e as escolhas lexicais no decorrer da sua atuação. Para tal, fez-se uma pesquisa de campo com os profissionais da área, que atuam no contexto educacional e os desafios encontrados na interpretação vocalizada. A pesquisa parte de uma análise das competências linguísticas e cognitivas que se fazem necessárias durante as suas escolhas lexicais e interpretativas de um texto-fonte (Libras) para o texto-alvo (língua portuguesa). Dentre os resultados obtidos, com os dados coletados no corpus desta pesquisa, percebe-se que o profissional precisa obter diversas competências linguísticas para realizar a tradução num fluxo contínuo e eficaz de uma língua para outra, e as escolhas terminológicas no sistema linguístico da língua portuguesa são amplas e complexas, haja visto que, a interpretação do enunciador tem relação com o sentido biológico e socioculturais que o TILSP se constitui cognitivamente.
\end{abstract}

Palavras-chave: Interpretação vocalizada. Língua Portuguesa/Libras. Competências linguístico-cognitivas. Contexto educacional.

\begin{abstract}
The article aims to analyze and investigate the linguistic skills that the Portuguese/Libras translator and interpreter - TILSP needs to obtain during simultaneous vocalized interpretation and the lexical choices in the course of their performance. To this end, a field research was carried out with professionals in the area, who work in the educational context and the challenges encountered in vocalized interpretation. The research starts from an analysis of the linguistic and cognitive skills that are necessary during their lexical and interpretive choices from a source text (Libras) to the target text (Portuguese language). Among the results obtained, with the data collected in the corpus of this research, it is clear that the professional needs to obtain several language skills to carry out the translation in a continuous and efficient flow from one language to another, the terminological choices in the linguistic system of the Portuguese language are broad and complex, given that the enunciator's interpretation is related to the biological and sociocultural sense that the TILSP is cognitively constituted.
\end{abstract}

Keywords: Vocalized interpretation. Portuguese Language/Libras. Linguistic-cognitive skills. Educational context.

\footnotetext{
${ }^{1}$ Universidade Federal do Espírito Santo, Departamento de Línguas e Letras, Programa de Pós-Graduação em Linguística, Vitória, ES, Brasil. Endereço eletrônico: fmachado.ufes@ gmail.com

${ }^{2}$ Universidade Federal do Espírito Santo, Programa de Pós-Graduação em Linguística, Vitória, ES, Brasil. Endereço eletrônico: leowanzeler@hotmail.com

${ }^{3}$ Universidade Federal do Espírito Santo, Programa de Pós-Graduação em Linguística, Vitória, ES, Brasil. Endereço eletrônico: rutigusmao2@gmail.com
} 


\section{Introdução}

O presente artigo tem por finalidade analisar e investigar as competências tradutórias e interpretativas a partir dos aspectos linguístico-cognitivos que o tradutor e intérprete de língua brasileira de sinais/língua portuguesa (TILSP) realizada durante a tarefa da interpretação simultânea direta de Libras para versão na modalidade vocalizada em língua portuguesa e os desafios que ocorrem no decurso do ato interpretativo no contexto educacional. As contribuições da Linguística Cognitiva para a intenção dessa pesquisa visam estudar a faculdade mental entre o objeto e o sujeito na qual a linguagem é o caminho que intermedia os conceitos abstratos e a comunicação entre os usuários da língua (LAKOFF, 1987; EVANS, 2019).

A Lei de $n^{\circ}$ 10.436, do dia 24 de abril de 2002, reconhece como "meio legal de comunicação e expressão a Língua Brasileira de Sinais - Libras e outros recursos de expressão a ela associados". Esse reconhecimento do uso da língua garante os processos linguísticos dos usuários surdos (sinalizantes) a se comunicarem em todos os contextos sociais e educacionais, com o direito de obterem o acesso à informação, à comunicação e à educação por intermédio da sua língua natural.

\footnotetext{
O signo linguístico não une uma coisa é uma palavra, mas um conceito e uma imagem acústica. Esta não é o som material, coisa puramente física, mas a impressão (empreinte) psíquica desse som. A representação que dele nos dá o testemunho dos nossos sentidos; tal imagem é sensorial, e se chegamos a chamá-la "material", é somente neste sentido, e por oposição ao outro termo da associação, o conceito geralmente mais abstrato. [...]. O caráter psíquico de nossas imagens acústicas, aparece claramente quando observamos a nossa própria linguagem [...]. (SAUSSURE, 2006, p. 80)
}

No entanto, para que a língua de sinais seja compreendida pelas pessoas nãosinalizantes, há a importância do TILSP realizar a mediação nos processos comunicativos e de interação com o surdo. Sendo por meio, dos aspectos linguísticos como objetivo de garantir a acessibilidade comunicacional entre os interlocutores sinalizantes e não-sinalizantes.

Temos como finalidade com essa pesquisa, coletar dados investigativos das quais são consideradas estratégias linguísticas utilizadas pelos TILSP na versão de interpretação simultânea vocalizada, tendo em vista os conhecimentos necessários linguísticos, tradutórios e interpretativos que surgem no ambiente escolar e são considerados desafiadores para os TILSP. A pesquisa busca observar as escolhas cognitivas e lexicais de acordo com as competências linguísticas no ato da interpretação direta vocalizada pelo TILSP e como ocorrem os processos da interpretação simultânea de uma língua-fonte/Libras para a língua-alvo/português. O profissional apropria-se do discurso do falante/sinalizante para realizar as suas escolhas lexicais 
no ato interpretativo de forma simultaneamente, na qual a sua atuação torna-se como ponte linguística no processo comunicativo entre surdos e ouvintes.

Na interface do ato da interpretação simultânea o TILSP realiza a apropriação discursiva que requer habilidades e competências linguísticas-cognitivas para realizar as escolhas lexicais no sentido de mediar a compreensão do discurso que fora enunciado pelo surdo para o receptor ouvinte. Para isso, a problematização da pesquisa elenca as seguintes questões: (a) No decorrer do ato interpretativo, ocorrem influências da Libras na sua construção sintática?, e (b) Ao longo da sua formação como tradutor e intérprete de Libras, houveram disciplinas direcionadas à interpretação de Libras para língua portuguesa na modalidade vocalizada? Por intermédio dessas perguntas, objetivamos dialogar sobre as estratégias e habilidades que esse profissional precisa adquirir para realizar a interpretação de Libras para língua portuguesa.

Dado o exposto, visamos alcançar as seguintes hipóteses: o TILSP precisa ter um léxico linguístico amplo nas duas modalidades linguísticas; as competências e habilidades linguísticas-cognitivas desenvolvidas no ato da interpretação simultânea, requer práticas e técnicas que influenciam no discurso; o surdo não enuncia sozinho, pois no ato interpretativo o TILSP utiliza-se de estratégias linguísticas que dialoga diretamente com os interlocutores.

Sabemos que a profissão de tradutor e intérprete de Libras está regulamentada pela Lei de $n^{\circ} 12.319$ registrada no dia $1^{\circ}$ de setembro de 2010 , a qual reconhece as competências do ato de interpretar entre duas línguas que são distintas entre si, ou seja, são línguas de modalidade gestualizada e vocalizada.

\footnotetext{
Art. 1ํㅡㄹ Esta Lei regulamenta o exercício da profissão de Tradutor e Intérprete da Língua Brasileira de Sinais - LIBRAS. Art. $2^{\circ} \mathrm{O}$ tradutor e intérprete terá competência para realizar interpretação das 2 (duas) línguas de maneira simultânea ou consecutiva e proficiência em tradução e interpretação da Libras e da Língua Portuguesa. [...] Art. 6- São atribuições do tradutor e intérprete, no exercício de suas competências: I efetuar comunicação entre surdos e ouvintes, surdos e surdos, surdos e surdos-cegos, surdos-cegos e ouvintes, por meio da Libras para a língua oral e vice-versa [...] (LEI FEDERAL 12.319/1 DE SETEMBRO, 2010).
}

Conforme citado anteriormente, o TILSP atua como um mediador da comunicação, ou seja, é um profissional que trabalha com a língua-fonte e a língua-alvo, proporcionando o acesso à informação e a interação entre sujeitos surdos e ouvintes. Durante a interpretação simultânea realizada diretamente na modalidade vocalizada o TILSP possibilita a legitimação e o empoderamento da voz discursiva do sujeito surdo por intermédio da sua entonação vocal e suas escolhas lexicais. No entanto, a subjetividade do profissional e as suas escolhas interpretativas podem ou não transmitir o que de fato o surdo em sua língua-fonte gostaria de enunciar para o receptor na língua-alvo (MACHADO, 2017, p. 45). Com isso, é o que 
apresentaremos na seção seguinte sobre os desafios que os TILSP enfrentam no cotidiano dos contextos educacionais.

\section{Os desafios do TILSP no contexto educacional}

A interpretação simultânea na modalidade vocalizada da língua portuguesa, traz a peculiaridade da responsabilidade da intercomunicação entre a língua-fonte e a língua-alvo. A prosódia ${ }^{4}$ e os contextos linguísticos escolhidos são fundamentais para que a "fala" (comunicação sinalizada) do sujeito surdo seja enunciada dentro dos seus objetivos de manifestação da linguagem. Segundo Pereira (2008), os códigos dos signos da língua de sinais possuem uma estrutura totalmente, independente gramaticalmente da estrutura sintática da língua portuguesa, isso significa que a interpretação simultânea ou consecutiva da Libras passa por inúmeras escolhas tradutórias e/ou interpretativas polissêmicas que estão ou não internalizadas no TILSP.

Os desafios da tradução e interpretação de Libras no contexto comunitário educacional são diversos, visto que, a escola é um organismo vivo, dinâmico e versátil com vários interlocutores que envolvem a comunidade escolar, o que conduz ao intérprete a atuar em diferentes campos do saber. Essa atuação perpassa por diversas estratégias e escolhas tradutórias-cognitivas, ao analisarmos a versão de modalidade vocalizada, percebe-se que nos contextos extralinguísticos e intersemióticos que englobam escolhas semântico-pragmáticas durante $\mathrm{o}$ ato enunciativo. Nesse sentido, identifica-se a pluralidade que o TILSP trabalha, esse profissional que visa à garantia da acessibilidade comunicativa de Libras para Português e viceversa, contemplando assim, o aluno surdo em sua totalidade. Sendo que este trabalho, em muitos contextos escolares, ocorre de forma autônoma e às vezes independentes, mesmo que haja outros profissionais da área da surdez.

O TILSP atua como um mediador linguístico durante um ato enunciativo das interlocuções entre surdos e ouvintes. A proximidade com o locutor-surdo, faz com que as suas escolhas interpretativas sejam mais coesas e coerentes ao discurso proferido na interpretação simultânea realizada diretamente na modalidade vocalizada do português, realizando assim, melhor adequação e adaptação no uso da linguagem e em sua prosódia para alcançar o receptor a compreensão da enunciação. Conforme a Lei de Inclusão de Inclusão de Pessoa com Deficiência - Estatuto da Pessoa com Deficiência (LBI, 2015), todos os contextos comunitários

\footnotetext{
4 “É a prosódia que molda nossa enunciação imprimindo a "o que se fala" um "modo de falar" que é dirigido intencionalmente ou não ao ouvinte" (BARBOSA, 2012, p. 13-14).
} 
que exige o direito ao acesso à justiça, à saúde e à educação são de suma importância ter um agente/profissional tradutor e/ou intérprete, e neste caso no Brasil nos referimos ao TILSP como um mediador da comunicação entre Libras e português, o que se faz necessário ao direito político linguístico. Com isso, de acordo com o estatuto da pessoa com deficiência, compreende-se que as:

[...] barreiras nas comunicações e na informação: qualquer entrave, obstáculo, atitude ou comportamento que dificulte ou impossibilite a expressão ou o recebimento de mensagens e de informações por intermédio de sistemas de comunicação e de tecnologia da informação. (LEI FEDERAL/LBI, 13.146/ JULHO DE 2015).

Nesse sentido, os direitos linguísticos dos usuários da Libras são reconhecidos e garantidos pela Lei Federal de $n^{\circ} 10.436$ de 24 de abril de 2002, e também pela Lei Federal de $\mathrm{n}^{\circ}$ 13.146 de julho de 2015, explana sobre os direitos das Pessoas com Deficiência - PCD's. Ambas as leis no Brasil esclarecem que não devem existir barreiras em comunicações e informações para as pessoas com deficiências. Sendo assim, para o sujeito surdo a legislação garante ao acesso à informação e à comunicação, pelo reconhecimento do uso da língua de sinais - Libras. Todavia, a legislação sofre os seus entraves nos aspectos comunicativos na sociedade, especificamente no espaço escolar quando o discurso é inclusão e acessibilidade comunicacional. Esses enfrentamentos dialógicos são amenizados, mas não sanados com a presença do TILSP e a nossa proposta não será discutir essa problemática, porém, consideramos não menos importante quando trata-se do TILS no contexto educacional.

Salientamos que, o surdo ao enunciar exerce autonomia no seu ato discursivo e empoderamento na sua fala-sinalizada, concretizando assim a sua linha de pensamento. Em algumas ocasiões, os surdos se anulam enquanto sujeitos discursivos, como explana a pesquisa. Com isso, a interpretação simultânea vocalizada tem o papel fundamental na emancipação do "falante”, o surdo-sinalizante na comunicação com ouvintes não-sinalizantes.

[o] problema, mais uma vez, reside em nosso desconhecimento em nossa ignorância em relação ao que se espera de nós e até ao que de fato vem a ser tradução simultânea. Aqui, como na maior parte das circunstâncias da vida, a expectativa condiciona os resultados. Se eu imagino que todos esperam de mim um desempenho impecável, digno de uma máquina perfeitamente construída para substituir palavras e conceitos, transladando-os com precisão a um outro universo semântico, sofro a cada pequena hesitação e ao primeiro lapso de memória ou pronúncia. Se imagino que não posso errar, e que todos na plateia estão ali para me julgar, crio um nível de tensão absurdo. [...] (MAGALHÃES JR., 2007. p. 65).

No ato da interpretação simultânea na modalidade vocalizada direta, o TILSP pode passar por alguns desafios que estão relacionados ao autojulgamento de suas próprias escolhas lexicais, como a indecisão e a não compreensão do discurso enunciado pelo usuário da Libras, 
entre outros aspectos que iremos discorrer neste artigo. Essas questões ocorrem, pois no cognitivo do TILSP, ele pode ou não, passar pela insegurança de não trazer a compreensão da informação durante suas estratégias interpretativas, o receio do público-alvo, o "medo da desmoralização e exposição pública". Essas questões podem acontecer principalmente com o profissional que está iniciando no campo da tradução ou interpretação. Portanto, acreditamos que além de todas as competências e habilidades que o TILSP deve exercer durante sejam quaisquer tarefas de tradução e/ou interpretação, o equilíbrio emocional, cognitivo e psicofisiológico é fundamental. (MAGALHÃES JR., 2007, p. 64-65).

\section{As competências interpretativas no ato da interlocução}

As competências comunicativas durante o ato da interlocução do TILSP ao longo da fala do emissor para o receptor são importantes para que haja uma compreensão da mensagem de uma língua-fonte para a língua-alvo. De acordo com Canale e Swain (1980), as competências comunicativas abrangem espaços que englobam o discurso, a emissão, a forma de falar e transmitir, ou seja, as competências comunicativas emanam outros tipos de competências como as competências estratégicas, linguísticas, sociolinguísticas e discursiva na qual o TILSP precisa colocar em prática, pois faz parte do seu ofício de transmitir a "mensagem ideal" de quem faz o discurso.

O discurso linguístico ocorre por meio dos processos cognitivos da linguagem que varia de indivíduo para indivíduo de acordo com a subjetividade (SAPIR, 1921, tradução nossa), que discorre como acontece esse meio sistêmico da comunicação "a linguagem não muda apenas gradualmente, mas de forma consistente, que ele se move inconsistente de um tipo para o outro"5 (SAPIR, 1921, p. 58, posição 1721 de 4583, tradução nossa). De acordo com Jakobson (1976, p. 19), “os fatores fundamentais da comunicação linguística”, ao qual perpassa qualquer ato de enunciação conversativa, entre o emissor, o comunicado e o sentido da mensagem.

Segundo Machado (2017), que discorre sobre o léxico-linguístico do TILSP que precisa ter durante a interpretação simultânea de Libras para o português na versão vocalizada, uma vez que, ele não enuncia sozinho e as possibilidades polissêmicas que o tradutor/intérprete realiza são complexas e diversas, o que não existe durante a interpretação simultânea o adequado e o inadequado, mas outrossim, são escolhas cognitivas, tradutórias e interpretativas diante do escopo linguístico e cultural que o TILSP tem no seu repertório linguístico-

\footnotetext{
${ }^{5}$ Tradução livre: [...] language has proven to us beyond all doubt that a language changes not only gradually but consistently, that it moves unconsciously from one type towards another [...] (SAPIR, 1921, p. 58, posição 1721 de 4583a).
} 
profissional. Para Canale e Swain (1980), que abordam assuntos referentes às "competências e os desempenhos", em relação ao conhecimento da gramática e o uso da língua, no qual concerne às "competências comunicativas" e as abordagens que ocorrem durante o "ato da fala" (CANALE; SWAIN 1980, p. 55, tradução nossa) são considerados primordiais para comunicação intra(inter)linguísticas. Desta forma, o TILSP precisa desenvolver diversas habilidades para efetivar uma melhor exposição vocálica do uso do retrospecto vocal.

Segundo Canale e Swain (1980), "[a] competência refere-se ao conhecimento da gramática e de outros aspectos da linguagem, enquanto o desempenho refere-se ao uso real ${ }^{7,}$ (CANALE; SWAIN 1980, p. 3, tradução nossa). Neste contexto, o TILSP precisa desenvolver habilidades cognitivas que permitirá a ele escolhas lexicais durante o ato performático do uso da fala numa tarefa da interpretação simultânea, pois esse processo ocorre de forma perspectivada, dicotômica, em relação a cognição e o discurso enunciado a ser traduzido e/ou interpretado, como se observa na figura 1 :

Figura 1 - Modelo de competências de Canale e Swain (1980)

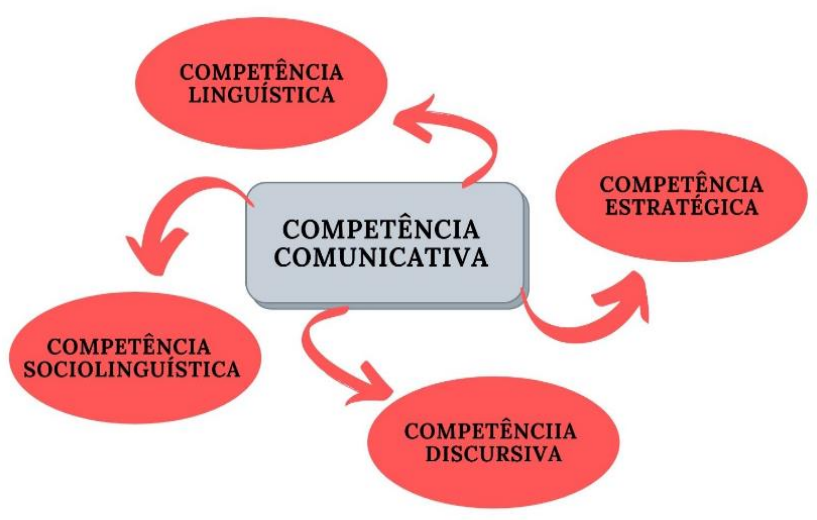

Fonte: elaborada pelos autores (2021).

As competências comunicativas, ilustradas na figura 1, vistas pelo modelo de Canale e Swain (1980), permitem que nós da área da tradução e interpretação de Libras, neste caso o TILSP, façamos a mediação do discurso entre a língua-fonte para a língua-alvo, por meio da tradução ou interpretação simultânea (ou consecutiva) realizada diretamente de Libras para a língua portuguesa na modalidade vocalizada, usando desde os recursos linguísticos, como: a prosódia, a sociolinguística que envolve o contexto sociocultural e as estratégias para o ato comunicativo. As competências comunicativas refletem nas escolhas cognitivas e lexicais do

\footnotetext{
${ }^{6}$ Ver o clássico Austin (1962) que fora desenvolvido a Teoria dos Atos de Fala. O "ato de fala", faz alusão ao conceito dos enunciados performativos, a partir do contexto dos sentidos discursivos pelos ouvintes para a comunicação da linguagem.

7 Tradução livre: [...] competence refers to knowledge of grammar and of other aspects of language while performance refers to actual use. [...] (CANALE, SWAIN, 1980. p. 3).
} 
processo de interpretação simultânea direta de Libras para língua portuguesa na modalidade vocalizada. O profissional se apropria da comunicação-sinalizada (fala) do surdo, durante esse processo comunicacional, onde que o TILSP realiza as escolhas lexemáticas durante o ato interpretativo simultâneo, estando totalmente de acordo com as competências linguísticas. Entende-se como competências linguísticas o conhecimento necessário para ser desenvolvido sobre determinado assunto que desempenham o léxico do uso da língua. No caso da interpretação simultânea vocalizada, o conhecimento da língua-fonte para a língua-alvo é necessário para que o discurso do transmissor em Libras seja realizado para a língua portuguesa na forma oral e auditiva. De acordo com Machado (2017), o tradutor e intérprete de Libras adquire competências e habilidades linguísticas para realizar uma tradução e/ou interpretação de forma eficaz e adequada, tais como:

[p]osicionamento; deslocamento - localização espacial; memória de curto prazo; expressão facial e corporal; raciocínio lógico e agilidade mental; improvisação; trabalho em equipe; atenção e concentração; percepção visual e auditiva; motricidade fina e percepção cinestésica; conhecimento linguístico. (MACHADO, 2017, p. 61-62)

Dessa forma, refletimos que para o tradutor ou intérprete que obter e alcançar uma dessas habilidades em seu processo performático durante a exposição vocálica, ele colocará em prática as competências linguísticas apresentadas na figura 1 deste artigo. Dentre as competências, temos também as habilidades que é possível perceber na articulação das competências comunicativas, a qual engloba a linguagem, a relevância e compreensão do receptor por meio do feedback dos usuários da língua. Contudo, compreendemos que as escolhas lexicais realizadas pelo TILSP em seu ato interpretativo simultâneo são de suma importância para eficácia de uma comunicação acessível. Segundo Machado (2017):

[...] entende-se que o ato de traduzir [também interpretar] não é uma simples transposição do léxico de uma língua à outra; isto é, não se traduz palavra por palavra, mas se faz necessário uma tradução [interpretação] de significados [semânticos] e das referências que há entre as culturas [...] (MACHADO, 2017, p. 44).

Essas competências e habilidades referidas, tornam-se necessárias para que o TILSP consiga mediar e transmitir o discurso enunciativo do texto-fonte para o texto-alvo, havendo uma qualidade do seu desempenho no ato interpretativo. É importante destacar que além dessas competências e habilidades, o TILSP, esse profissional tradutor/intérprete precisa conhecer por meio de formação acadêmica, fazendo uso com propriedade das duas modalidades linguísticas - Libras/português. Ou seja, ter acesso ao texto-fonte previamente para realizar uma interpretação simultânea, o que é relevante objetivando um amplo conhecimento lexical das 
línguas envolvidas, como também de conhecer o contexto cultural dos usuários das línguas, para que o TILS realize seja qual for a tarefa de tradução ou interpretação.

\section{Os desafios da interpretação simultânea vocalizada}

As escolhas lexicais do TILSP, ao mediar o enunciado do discurso, requerem um processo tradutório cognitivo na qual "[a] aquisição da competência tradutória seria, assim, um processo de automatização gradual e de reflexão crítica" (HURTADO, 2005, p. 26). Todavia, o processo comunicativo e linguístico percorre de acordo com o contexto histórico e social do sujeito, que é influenciado pela subjetividade em que as estratégias se transformam de acordo com as práticas tradutórias e/ou interpretativas. De acordo com Jakobson (1976):

[...] o significado pode e deve ser expresso em termos de discriminações e identificações linguísticas, assim como, de outra parte, as discriminações linguísticas são sempre feitas em função de seu valor semântico. As reações das pessoas às línguas que falam, ou - como se poderia dizer hoje —, as "operações metalinguísticas", são proposições equacionais que surgem tão logo haja incerteza quanto a se ambos os interlocutores usam o mesmo código verbal e em que medida o discurso de um é compreendido pelo outro. Tais interpretações metalinguísticas de uma mensagem, através de paráfrases ou de efetiva tradução em outra língua, ou mesmo num diferente conjunto de signos, desempenham papel de enorme importância em qualquer processo de aprendizado de linguagem, tanto nas crianças como nos adultos. (JAKOBSON, 1976, p. 92-93).

O TILSP, ao realizar a interpretação simultânea vocalizada da língua-fonte (Libras) para a língua-alvo (português oralizado), está remetido às escolhas lexicais, referenciando ao uso da prosódia conforme o enunciador no sentido de alcançar o discurso pretendido do surdo e a compreensão do ouvinte. Jakobson (1976) analisou fatores que são considerados:

[...] fundamentais da comunicação linguística: qualquer ato de fala envolve uma mensagem e quatro elementos que lhe são conexos: o emissor, o receptor, o tema (topic) da mensagem e o código utilizado. A relação entre esses quatro elementos é variável. (JAKOBSON, 1976, p. 19).

Durante o ato interpretativo simultâneo, o TILSP se apropria do discurso do surdo e passa a enunciar a mensagem proferida, proporcionando o sentido para compreensão do receptor que recebe a informação em língua portuguesa. Dessa maneira, ele trabalha a sua consciência fonológica $^{8}$ e a consciência prosódica ${ }^{9}$ que vai ao encontro da alocução do enunciado. De acordo com Piccolotto e Soares (1977), "para criar conforto[,] você deve falar a linguagem da pessoa [...], [e] o primeiro passo é observar o vocabulário e as expressões

\footnotetext{
${ }^{8}$ Ver Capovilla (1997). A consciência fonológica está intrínseca na "Consciência Metalinguística” e, de acordo com Morais (1991), a consciência fonológica tem a competência de processamento de ações cognitivas por meio da fala.

${ }^{9}$ Segundo Morais (1991), a "Consciência Prosódica" envolve os aspectos da consciência fonológica holística que corresponde à entonação prosódica vocálica e a maneira de como conduzir o discurso.
} 
idiomáticas usadas". Neste ponto de vista, podemos associar ato interpretativo e performático do TILSP durante a versão direta vocalizada, uma vez que a modulação da voz precisa ser confortável e acessível aos interlocutores do discurso, criando uma conexão no uso do vocabulário com a narrativa do enunciador e uma conexão com o receptor em relação ao retrospecto vocal do TILSP em sala de aula.

Os padrões da fala do TILSP referentes às escolhas lexicais são notáveis, e um dos pontos importantes no ato enunciativo diz respeito à agilidade da emissão, estando condicionado à compreensibilidade que o intérprete tem sobre a mensagem. $\mathrm{O}$ desempenho da sua performance irá influenciar diretamente na comunicação e no processo da interlocução. A tonalidade e a impostação vocal, além das emoções que irá colocar no retrospecto vocal nas escolhas lexicais que podem ocasionar sensações positivas ou negativas ao público-alvo.

Segundo Chun (2002, p. 14), as características da prosódia são a "frequência (ou tom), intensidade (ou volume), duração (ou comprimento), estresse, sotaque e ritmo são definidos e discutidos em termos de como eles são percebidos pelos ouvintes" ${ }^{10}$. Os aspectos da enunciação refletem no interlocutor os sentidos da língua-fonte, a incumbência da fala pode expressar significados semântica-pragmáticos, o que é possível proporcionar a coesão e a coerência com o ato discursivo.

\section{Resultados e análises do corpus da pesquisa}

A proposta se realizou por meio de uma pesquisa qualitativa, com a finalidade de analisar, investigar e compreender o envolvimento dos participantes tradutores e intérpretes de Libras/língua portuguesa no contexto comunitário educacional, sobre as percepções profissionais da tarefa do ato da interpretação simultânea na modalidade vocalizada da Libras/língua portuguesa.

A pesquisa em questão teve como metodologia uma pesquisa participativa pública e de análise das respostas dos entrevistados, a fim de compreender os obstáculos e desafios encontrados no ato interpretativo simultâneo do uso da voz na língua portuguesa quando visualizando os sinais manuais da Libras do usuário da língua, e assim analisando, os processos cognitivos que ocorrem durante a tarefa de uma interpretação simultânea. A partir da análise dos dados coletados dos 13 participantes que aceitaram contribuir com a pesquisa, respondendo ao questionário que fora elaborado via Google Forms, com questões fechadas (objetivas) e abertas (dissertativa). Durante a "Pesquisa de Interpretação Vocalizada Libras/Língua

\footnotetext{
${ }^{10}$ Frequency (or pitch) intensy (or loudness, duration (or length), stress, accent, and rhythm are defined and also discussed in terms of how they are perceived by hearers [...] (CHUN, 2002, p. 14, tradução nossa)
} 
Portuguesa", foi possível coletarmos informações relevantes para esse artigo, principalmente quanto aos referentes à formação dos participantes que atuam como TILSP na área educacional, exercendo a tarefa de tradutores e/ou de interpretação simultânea. Neste mesmo questionário, identificamos que os participantes possuem idades variadas entre 23 e 60 anos.

As questões elaboradas são alusivas às competências linguísticas dos profissionais TILSP em relação ao processo de Interpretação Simultânea Vocalizada (ISV). Referente à atuação do TILSP no contexto educacional, dos participantes obtivemos as seguintes informações de respostas selecionadas: no ensino infantil foram 38,5\%; no ensino fundamental I e ensino superior as respostas foram de 53,8\%; no ensino fundamental II obtivemos o maior percentual de $84,6 \%$ da resposta selecionada pelos participantes; e por fim, no ensino médio forma 76,9\% das respostas encontradas. Já no gráfico 2 apresenta-se as informações referente a formação dos participantes em relação área da Tradução e Interpretação de Libras/português - TILSP, tendo como base o Decreto de ${ }^{\circ} 5.626 / 2005$, visto no capítulo V do texto do artigo 17 e $18:$

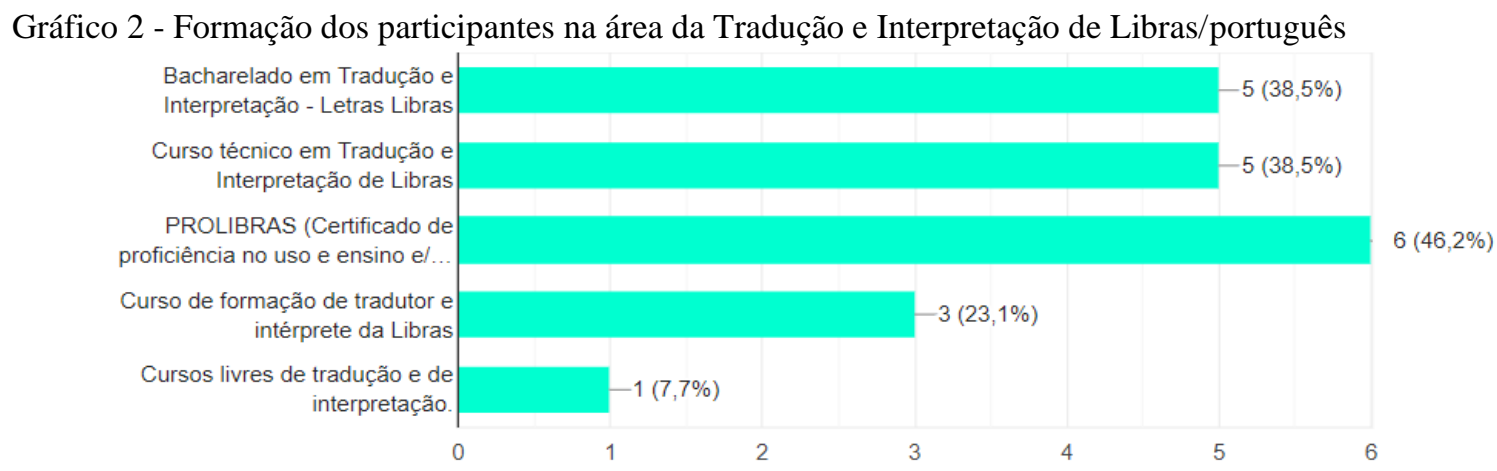

Fonte: elaborado pelos autores (2021).

No gráfico 2, nota-se que os dados revelam que a formação acadêmica do participante dessa pesquisa fora selecionada com os seguintes percentuais: dos 13 participantes, obtivemos $38,5 \%$ que possuem o curso de graduação em Bacharelado Letras-Libras, e na mesma porcentagem, percebe-se que os outros $38,5 \%$ possuem a formação no curso técnico em Tradução e Interpretação de Libras. No entanto, observamos que 46,2\% dos participantes possuem o certificado de proficiência em Libras, conhecido como Prolibras (MEC), e somente 23,1\% dos participantes registraram que possuem o curso de extensão de formação de Tradução e Interpretação da Libras. Por fim, com 7,7\% dos participantes possuem o curso livre de Tradução e Interpretação da Libras. O que se destaca nesses dados é que o maior público dos participantes da pesquisa é de $69,2 \%$ do sexo feminino e $30,8 \%$ do sexo masculino, o que evidencia que no contexto educacional a grande maioria ainda é de mulheres que atuam nesse 
contexto. Observando, temos o gráfico 3 que apresenta o nível de formação acadêmica dos participantes da pesquisa:

Gráfico 3 - Formação acadêmica dos participantes

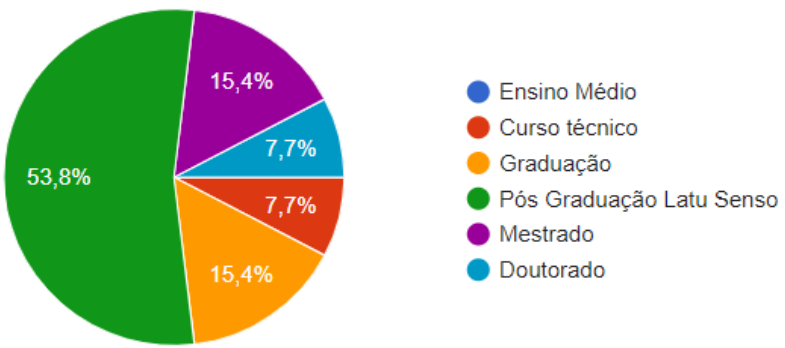

Fonte: elaborado pelos autores (2021).

O gráfico 3, mostra que 53,8\% dos participantes possuem Pós-Graduação Latu Senso, e somente 15,4\% possuem Pós-Graduação Strictu Sensu ou alguma graduação, o que demonstra o conhecimento amplo do uso do léxico em língua portuguesa e potencializa ainda mais as estratégias cognitivas que o TILS organiza durante a tarefa da interpretação simultânea.

Abaixo, apresentamos as questões que foram discursivas do questionário em que enviamos aos TILS que atuam diretamente no contexto educacional e que também aceitaram participar dessa pesquisa. As respostas obtidas são de três questões e a seguir estão divididas no quadro 1, quadro 2, quadro 3, quadro 4 e quadro 5, seguido da questão apresentada no Google Forms e as respostas dos participantes na íntegra sem alteração ou correção do texto redigido pelo participante. Inicialmente, o quadro 1 busca os dados coletados sobre as estratégias linguísticas que são desenvolvidas no contexto escolar quando realizadas para a tarefa da interpretação simultânea vocalizada:

Quadro 1 - Pesquisa de Interpretação Vocalizada Libras/Língua Portuguesa

\begin{tabular}{|l|}
\hline $\begin{array}{l}\text { Questão } 8 \text { - Quais as estratégias linguísticas desenvolvidas no contexto educacional a fim de realizar uma interpretação } \\
\text { vocalizada? }\end{array}$ \\
\hline 1- Várias, são usados exemplos classificadores. \\
\hline 2- Uma conversa prévia com o aluno ou professor surdo para contextualização do tema a ser traduzido \\
\hline 3- Voz \\
\hline 4- Adequação ao nível lexical. \\
\hline $\begin{array}{l}\text { 5- Primeiramente conhecer a linguagem da disciplina que estou interpretando, para assim com esse conhecimento trabalhar } \\
\text { minhas estratégias na interpretação para Libras, e assim fazer a construção linguística da língua de partida para a língua-alvo, } \\
\text { adequando para uma melhor interpretação vocalizada e trabalhando a minha interpretação vocal, sabendo que a escrita nos } \\
\text { comunicamos de uma forma, e o vocal ou a Locução adequamos para conseguirmos uma interpretação ideal. }\end{array}$ \\
\hline 6- Conhecimento. \\
\hline 7- Adequar para o português a fala em Libras de forma a trazer o sentido de todos os parâmetros necessários para essa transição.
\end{tabular}


8- Entonação para dar destaque ou diferenciar estados emocionais, Intensificação do sentido do discurso com expressão facial e corporal também.

9-Conhecer a Língua Portuguesa e os sinônimos.

10-Estabelecer familiaridade com a sinalização dos envolvidos; em caso de eventos ou aulas com falas pré-planejadas (apresentações, palestras etc.) perguntar previamente qual será o conteúdo tratado; estabelecer certos acordos, quando possível, sobre, por exemplo, sempre realizar a datilologia prévia de termos específicos, antes do sinal, assim como "pronunciar (mouthing)" junto aos sinais de acepção específica; manter um lag time significativo que ofereça segurança; etc.

11-No ensino médio, às vezes eu fazia simultâneo, pois o surdo tinha mais conhecimento linguístico, e as suas falas eram mais claras.

No ensino fundamental, a aluna não conhecia a libras, por isso era muito difícil dar voz, assim eu tentava adivinhar seus gestos e construía a frase no português de acordo que eu tinha entendido, sempre após o término de sua fala. Às vezes, pela dificuldade com a comunicação, eu entendi errado a sua fala.

12- Domínio da Língua de Sinais e da Língua portuguesa

13- Competência linguística da língua-fonte e habilidade linguística em ambas as línguas.

Fonte: elaborado pelos autores (2021)

De acordo com o quadro 1, foi possível compreender que os participantes relataram a importância de conhecer o conteúdo previamente antes de realizar seja qual for o conteúdo para uma interpretação simultânea. Os participantes relatam que é também importante que o TILSP conheça o contexto do currículo do aluno, os planejamentos do professor de sala de aula, para que ele possa se preparar antecipadamente realizando as escolhas linguísticas e culturais da língua-fonte para a língua-alvo, além de fazer as possíveis adaptações lexicais, conforme o nível de compreensão do estudante-surdo em sala de aula. Na sequência, observa-se o quadro 2, que procura identificar os conhecimentos necessários para uma interpretação vocalizada:

Quadro 2 - Pesquisa de Interpretação Vocalizada Libras/Língua Portuguesa

Questão 9 - Você consegue destacar os conhecimentos necessários para a interpretação vocalizada?

1- $\mathrm{Sim}$

2-Um bom domínio do português formal, e pelo menos uma noção do tema a ser abordado

3- Depende

4- Conhecimento/fluência nas duas línguas. Habilidades de oratória como fluência, entonação e outros, coerência e coesão textual.

5- Conhecer a língua de partida com naturalidade, e a língua-alvo também.

Conhecer as diferenças de locuções, por exemplo, os tipos de textos que irá interpretar, ou o assunto, para que consiga fazer essa vocalização com naturalidade.

Conhecer o seu timbre de voz e trabalhar as entonações vocais.

Conhecer o seu público-alvo, porque assim vai conseguir adequar suas colocações sem causar estranhamentos.

6- Conhecimentos tradutórios e conhecimento linguístico

7- Através da voz é necessário espelhar as emoções, transparecer o estado de espírito, passar a função que o discurso quer afetar. A voz deve passar credibilidade e segurança, bem como cuidar da entonação, altura da voz, articulação e velocidade da fala, alternando esses dois últimos aspectos para uma comunicação expressiva. Deve-se conhecer a temática e fazer escolhas lexicais adequadas bem como captar o perfil do sinalizador: cultural, social, personalidade. Ser quase um Sherlock Holmes da interpretação 
8- Experiência e conhecimento prévio do conteúdo a ser interpretado são imprescindíveis, mais até do que na interpretação sinalizada.

9- No meu caso apresento dificuldades, nesse quesito.

10- Competência tradutória intermodal com destaque: para o domínio da língua em sua oralidade; para a boa articulação vocal com uma impostação adequada; e, por fim, para a capacidade de leitura da sinalização em língua de sinais.

11- A pessoa precisa ser fluente em libras, ter experiência com interpretação simultânea. Acredito que conhecer o surdo ajuda, pois com a interação, vocês já conhecem as estratégias de comunicação usadas pelo surdo. Com um surdo que você não conhece, às vezes você pode se equivocar, principalmente pq, muitos surdos combinam sinais com intérpretes, e você não conhece aquele sinal, ou aquele estilo de fala, de forma de comunicar, e acaba se perdendo durante a interpretação. Já quando encontramos surdos de outras cidades, ou estados, a interpretação se torna muito mais complicada, pois, além do jeito de falar ser muito diferente, o regionalismo acaba sendo um grande empecilho na interpretação, por desconhecimento do sinal usado naquela região, por exemplo a mandioca e o aipim, citados em qualquer curso básico.

12- Conhecer o surdo sinalizante, sua estratégia de formação das franceses, dominar a língua portuguesa, possuir vocabulário e ter um convívio com os Surdos.

13- Imersão na língua-fonte, utilizar com propriedade de conhecimento a gramática funcional da língua-alvo

Fonte: elaborado pelos autores (2021).

$\mathrm{Na}$ quadro 2, trata-se sobre os conhecimentos necessários para a interpretação simultânea vocalizada, visto que os participantes relatam sobre a real importância em ter conhecimento gramatical entre as duas línguas de uso (Libras e português), habilidades e adequações prosódicas, adequação do uso do léxico e respeitando o público-alvo, ter experiência (prática interpretativa), competência tradutória intermodal para a tarefa da interpretação simultânea, que vão além de estratégias de comunicação, como também conhecer o regionalismo linguístico e cultural, e não menos importante, se apropriar do uso gramatical de forma sistêmico-funcional das línguas envolvidas. A seguir, o quadro 3 tem como finalidade de obter os resultados o número de vezes que o aluno-surdo faz uso da interpretação vocalizada:

Quadro 3 - Pesquisa de Interpretação Vocalizada Libras/Língua Portuguesa

\begin{tabular}{|l|}
\hline $\begin{array}{l}\text { Questão } 10 \text { - Com que frequência o sujeito surdo requer este recurso de interpretação vocalizada no contexto } \\
\text { educacional? }\end{array}$ \\
\hline 1- Sempre \\
\hline $\begin{array}{l}\text { 2-Isso varia muito, pensando no aluno surdo, já tive alunos que em todas as aulas queriam participar de alguma forma, com } \\
\text { algum comentário para a turma ou para o professor, mas já tive vários outros que só requisitavam tradução oral em dias de } \\
\text { apresentação de trabalho ou quando o professor fazia uma pergunta diretamente a ele. E essa segunda possibilidade são a } \\
\text { maioria dos casos. }\end{array}$
\end{tabular}

3- Depende da pessoa surda

4- Vejo no contexto educacional a criança/ estudante surdo, o requer desse recurso por parte deles envolve fatores com segurança no espaço que está incluso, relação com professores, intérpretes e outros colegas. Quando se sentem à vontade e bem acolhidos se manifestam mais e solicitação mais a tradução vocalizada. Os professores surdos solicitam essa versão sempre que estão em contato com ouvintes não usuários de Libras. Pode ser em aulas, planejamentos, reuniões e até mesmo em momentos de bate-papo em intervalos.

5- Em sua grande maioria em apresentações de trabalho, em conversas com seus colegas e professores, com o pedagógico.

6- raramente 
7- muita frequência

8- É muito comum essa modalidade em um contexto educacional, mas depende muito do perfil do surdo que estamos acompanhando, pois que, se na sala de aula esse surdo é mais tímido não costuma querer se posicionar, assim nossa prática se restringe mais em sinalizar conteúdo.

9-Nem sempre.

10-A tradução para a voz é pouco usada em ambientes educacionais, o mais comum é a interpretação da língua de sinais para o português oral, a qual é demanda constantemente em todas as interações em que há diálogo entre falantes de língua de sinais e de língua vocal.

11-Sempre que tem dúvidas da matéria. Nas apresentações de trabalho escolar. Reuniões de grupos para trabalhos, quando são feitas em horário de aula, o aluno pede ajuda para, além de entender o que o grupo está falando, para dar a sua opinião também. E tem questões pequenas, como quando o aluno pede para ir ao banheiro, ou beber água. Ou pede algo para a secretária, e às vezes na hora do lanche, na cantina.

12- Bem, pelo tempo de experiência percebo que alguns surdos não opinam e questionam durante as aulas, sempre é necessário que o intérprete incentive essas ações, sendo assim no âmbito educacional pouco faço o uso da direção Libras/Português

13- Em apresentações de trabalho, quando ele quer interagir com o professor, tirar dúvidas, na secretaria... praticamente em todo âmbito escolar

Fonte: elaborado pelos autores (2021).

Em conformidade com as respostas dos participantes, o quadro 3 apresenta que, a interpretação vocalizada não ocorre com frequência no contexto educacional, salvo as situações nas quais os discentes precisam realizar alguma apresentação de trabalho ou dialogar com os colegas (alunos) não-falantes da Libras. O Quadro 4, procura salientar os desafios linguísticos que os TILSP participantes da pesquisa encontram na interpretação vocalizada no contexto escolar:

Quadro 4 - Pesquisa de Interpretação Vocalizada Libras/Língua Portuguesa

Questão 11 - Quais os desafios linguísticos que você encontra no processo de interpretação vocalizada no contexto escolar?

1- Muitas vezes o aluno não é normalizado.

2- Pelo menos no ensino fundamental, os surdos tinham uma grande dificuldade em discorrer um tema, principalmente quando a turma toda estava focada nele. Assim vocalizar a fala dele sendo o mais ético possível, sem acrescentar ou tirar informações era difícil.

3- Letramento da libras pela pessoa surda ou até mesmo do tils

4- Como minha experiência é na Educação Infantil e no ensino fundamental, as crianças e estudantes surdos em sua maioria fazem uso de gestos, sinalização descritiva de relatos, classificadores e expressões corporais e faciais. Nesse contexto, o desafio é compreender com clareza o discurso da criança para ser fiel na interpretação. Assim com Interpretar professores surdos para público ouvinte da Educação Infantil e Ensino Fundamental exige escolhas lexicais próximas as idades e experiências significativas às crianças ouvintes. Conhecer o público a quem a informação é dirigida para melhores escolhas de interpretação.

5- Na maioria das vezes o vocabulário, a Escola é um lugar onde se fala de tudo, saímos da medicina para a engenharia, e o intérprete precisa se virar para a interpretação de Libras e a Vocalizada, tendo assim um grande desafio.

6- Neste momento não vejo dificuldade, porém a dificuldade do aluno em aprender conteúdo que ele irá sinalizar, pode prejudicar a vocalização do intérprete 
7- Por vezes o surdo não tem 'VOZ'. O intérprete é visto como o autor da opinião, mesmo quando esta vem do surdo. Vestem o surdo com uma carapuça de subalternidade e coloca sobre o ouvinte as responsabilidades, seja de tarefas, seja na fala da interpretação.

8- Já tive situação de ser chamada na sala do diretor e me deparar com pai de aluno, surdo também, agitado, e ter que vocalizar um assunto que eu não tinha a menor ideia do que se tratava, tive muita dificuldade de entender a sinalização e vocalizar.

9-Fazer a interpretação e adaptar linguisticamente para Língua Portuguesa.

10- Os mesmos encontrados no processo de sinalização, com destaque para o fato de que linearizar em língua vocal um grande volume de informações simultaneamente codificadas em língua de sinais, demanda diversas habilidades de síntese, as quais estão ancoradas em macroestratégias de simplificação, generalização e omissão, por exemplo.

11- Sinceramente, o maior desafio é conseguir conteúdo das aulas previamente para adaptação.

12- Meu maior desafio é incentivar o Surdo participar, interagir e opinar. Em alguns casos as limitações de conhecimento sobre o tema, ter acesso aos conteúdos que serão usados nas aulas, pouco sinalário usado pelo surdo e pouca prática na interpretação Libras/Português

13- Nenhuma

Fonte: elaborado pelos autores (2021).

De acordo com o quadro 4, é possível identificar as variáveis que o TILSP enfrenta em relação aos desafios linguísticos durante a tarefa da interpretação simultânea vocalizada no contexto escolar. Conseguimos perceber nesses dados coletados que foram esboçadas de forma dissertativa pelos participantes, que a maioria apresenta as experiências profissionais de forma empírica, o que se percebe é que os desafios dos TILSP são diversos para a uma tarefa de interpretação vocalizada. Os relatos registrados pelos participantes são as barreiras comunicativas em diferentes aspectos do ambiente escolar; os processos performáticos que o aluno-surdo tem ao se expressar em Libras na escola; o não-acesso previamente do conteúdo que será interpretado simultaneamente na sala de aula; a omissão, anulação e a dificuldade que o discente-surdo tem ao interagir durante as aulas. E concluindo, o quadro 5 evidencia a formação do TILS que atuam no contexto escolar em relação às disciplinas que cursos proporcionaram ao TILSP, durante a trajetória acadêmica, no que se refere a interpretação vocalizada:

Quadro 5 - Pesquisa de Interpretação Vocalizada Libras/Língua Portuguesa

Questão 12 - Na sua formação como tradutor e intérprete de Libras, você teve disciplinas direcionadas à interpretação de Libras para Língua Portuguesa vocalizada?

1- Sim

2- Na minha formação superior a disciplina de libras foi puramente teórica e os cursos de libras que já fiz, ficavam majoritariamente na libras sinalizada e não oral.

\section{3- Sim}

4- Não 
5- Tive uma disciplina, e assim muito pouco, para a responsabilidade que é. Posso dizer isso com uma propriedade maior, porque sou estudante de Rádio e TV, e todas as disciplinas trazem a Locução, e temos uma disciplina específica de locução, e como é importante para nós sabermos interpretar de forma oral um texto, passar através da nossa voz o sentimento do que é nos apresentado. Isso porque normalmente é uma interpretação intralingual. Agora a dificuldade aumenta muito mais porque estamos falando de uma interpretação Interlingual, e precisando ter muito mais competências além de saber fluentemente as duas línguas.

6- Não

7- Não

8- No curso técnico jamais, agora na graduação sim.

9- Sim. Mais no Ensino Médio e Superior

10- Realizei cursos livres com enfoque em vocalização/interpretação para o português oral.

11- Não

12- Em alguns cursos de aperfeiçoamento realizados de Tradução/Interpretação e Estratégias Tradutória.

13- Não

Fonte: elaborado pelos autores (2021).

De acordo com o quadro 5, a questão norteadora menciona se o tradutor e intérprete teve disciplinas direcionadas à interpretação de Libras/língua portuguesa vocalizada em sua formação. Durante as análises é possível perceber que seis dos participantes não tiveram essa disciplina de interpretação vocalizada, sendo que os demais foram três que tiveram uma disciplina de formação em que dialogou especificamente sobre a interpretação vocalizada e somente um dos participantes disserta no relato de que houve uma disciplina de formação, e o mesmo considera que fora uma formação ministrada de forma superficial. O participante 08 , relata que durante o curso técnico não foi ofertada disciplina que enfatiza a interpretação vocalizada, no entanto, ele relata que na graduação em Letras-Libras estas questões foram dialogadas. Destacamos ainda, que o participante 10 possuem somente a certificação do Prolibras, e o participante 12 concluiu o curso de formação em Tradutor e Intérprete de Libras, porém ambos, ao longo das experiências profissionais, os cursos livres e de aperfeiçoamento em práticas de interpretação para uso do retrospecto vocal foi a forma de garantir qualidade performática para mediar a comunicação no contexto escolar.

Além do quadro 1, quadro 2, quadro 3, quadro 4 e quadro 5, foi realizado um questionamento a respeito das influências linguísticas (alternância de código) no processo de interpretação vocalizada em relação à construção sintática de Libras para o português. Os dados registrados foram que em torno de $61,5 \%$ "às vezes" surgem influências linguísticas, e 23,1\% dos participantes "sempre" se deparam com a influência linguística para construção sintática dos enunciados, e somente $15,4 \%$ dos participantes registraram que "nunca" tiveram nenhum problema com alternância de código linguístico durante o processo de interpretação simultânea 
vocalizada.

Essa pesquisa evidencia que dos 13 participantes, totaliza-se que em torno de 84,6\% sofrem influências linguísticas (alternância de códigos linguísticos) durante a tarefa da interpretação simultânea vocalizada. Com isso, diante dos dados coletados, compreendemos que mesmo com essa mostra ensaísta, ainda necessitamos de pesquisas que se debruçam em apresentar uma formação que abrangem também a interpretação simultânea vocalizada aos TILSP que atuam contexto educacional, ou jurídico e clínico de uma interpretação vocalizada, que é uma tarefa que exige muito do TILSP em suas competências e habilidades linguísticas e cognitivas. E compreendemos que precisam estar a ementa na grade curricular dos cursos de formação, com o propósito de dar conta de todo esse esforço cognitivo que o TILSP precisa realizar quando envolvido no processo de leitura e interpretação das línguas envolvidas. De acordo com os princípios da Linguística Cognitiva, Machado (2017, p. 201) esclarece que os TILSP em relação à tradução e/ou a interpretação de conceitos, vocabulários e terminologias são estruturas linguísticas que "projetam a realidade de acordo com nossas experiências", sejam acadêmica-profissional ou empíricas por meio de contato com a comunidade surda e com o conteúdo a ser traduzido/interpretado. Essas construções subjetivas ocorrem por meio das relações e aquisição de conhecimento de cada sujeito diante de uma interpretação simultânea que envolve a língua portuguesa na modalidade vocalizada e a Libras que é expressa gestualmente pelo usuário da língua.

\section{Considerações finais}

Os desafios e obstáculos encontrados nessa pesquisa sobre a interpretação simultânea vocalizada do TILSP perpassam por práticas desafiadoras em que os cursos de formação ainda pouco explorados para esse processo performático, essa prática interpretativa simultânea vocalizada. O TILSP no decorrer da prática da interpretação simultânea vocalizada acaba colecionando por meio de experiências as estratégias linguísticas e cognitivas de como atuar no contexto educacional a partir das falas-sinalizadas dos alunos surdos. Neste sentido, observa-se que o TILSP precisa ser polivalente em suas escolhas interpretativas, e também, desenvolver habilidades no processo comunicativo para a tarefa da tradução e/ou interpretação, sendo ela adquirida de forma empírica, no sentido de promover soluções de problemas que podem surgir durante a interpretação simultânea no contexto educacional.

As competências comunicativas e as habilidades são imprescindíveis para realização de uma interpretação simultânea vocalizada, uma vez que muitos dos participantes desta pesquisa relataram por meio de suas experiências, que a maior parte das formações acadêmicas ofertadas, 
não houve uma disciplina que contemplasse a necessidade do processo de ensino e aprendizagem do TILSP-estudante em relação às estratégias e práticas interpretativas quanto ao uso da voz da língua portuguesa, ou seja, como o TILS-estudante precisa realizar uma interpretação simultânea da Libras para Língua Portuguesa na modalidade vocalizada. Consideramos fundamental esse conhecimento adquirido por meio de formações acadêmicas, pois capacita ao TILSP para o mercado de trabalho, e certamente toda a prática in loco o aperfeiçoa à medida que o TILSP amplia o conhecimento na área.

Os processos cognitivos no TILSP ocorrem de forma associativa ao processo de aprendizado e a assimilação do conhecimento adquirido. Em outras palavras, todo o processo cognitivo (FELTES, 2007; MACHADO, 2017) é uma atividade cerebral que realizamos cotidianamente, e a partir do processo cognitivo que o TILSP desenvolve as capacidades intelectuais e emocionais. Ou seja, toda a interpretação simultânea das informações armazenadas auditivamente pelo cérebro é de total competência cognitiva, isto é; a linguagem, memória, raciocínio, capacidade de compreensão, percepção, leitura-audita dentre outros, são processos que permitem o TILSP a compreender e realizar interpretação simultânea em qualquer contexto ou situações que exige a mediação de uma comunicação acessível entre surdos e ouvintes, posicionando as relações entre os usuários da língua que visam assimilar, interpretar e representar visualmente a Libras para o português na modalidade vocalizada.

Podemos concluir que, durante a interpretação simultânea na modalidade vocalizada da língua portuguesa não consideramos de "está certo" ou "está errado" uma interpretação simultânea, mas sim, o TILSP realiza escolhas interpretativas conforme o seu conhecimento linguístico e cultural, e a própria prática de atuação. À medida que o TILSP desenvolve as habilidades performáticas que exige toda a tarefa da interpretação simultânea, recomenda-se que busque nas competências cognitivas elementos que permite realizar seja quaisquer tarefas de tradução e/ou interpretação no contexto educacional ou em outros contextos comunitários que se desdobram como o direito à educação, saúde e jurídica.

Dessa forma, a modalidade vocalizada está correlacionada a prosódia, e caracteriza-se pelo uso linguístico gramatical e cultural, pois observamos como elemento fundamental da comunicação, e se não aplicado de forma compreensível pode impactar diretamente na compreensão do entendimento da língua-fonte para língua-alvo num processo de interpretação simultânea. Com isso, os aspectos cognitivos são estudos da relação entre diferentes funções cerebrais associada à linguagem e à comunicação. O TILSP que atua no contexto educacional é um profissional que faz uso da capacidade cognitiva com um conjunto diverso de disciplinas, conhecimentos variados e desafiadores, o que requer um estudo contínuo do currículo escolar 
na qual está inserido num mundo multissemioticamente constituído. E isso, são resultantes de nossas múltiplas experiências psicossociais que integram ações de uma e outra área à estreita relação com a mente e o corpo. Em suma, a cognição é o organismo vivo da tarefa de traduzi e/ou interpretar, é a dimensão pragmática da cognição humana, da natureza sociocognitiva (não meramente neurobiológica) da plasticidade cerebral, da concepção de cérebro como sistema funcional dinâmico, corporificado e simbólico, não redutível ao substrato físico ou orgânico. Sendo assim, acreditamos que o ato de interpretar simultaneamente uma língua de modalidade gestual (Libras) para a língua portuguesa, que é uma modalidade vocalizada, é uma tarefa complexa e explora de forma ampla e profunda todas as capacidades cognitivas de um profissional, neste caso referimos exclusivamente ao TILSP.

\section{Referências}

AUSTIN, J. L. Philosophical Papers. Third Edition. Oxford: Oxford Press, 1979.

BARBOSA, P. A. Conhecendo melhor a prosódia: aspectos teóricos e metodológicos daquilo que molda nossa enunciação. Rev. Est. Ling, Belo Horizonte, v. 20, n. 1, p. 11-27, 2012.

BRASIL. Lei n. 10.436, de 24 de abril de 2002. Dispõe sobre a Língua brasileira de sinais - Libras e dá outras providências. Brasília, DF, 2002.

BRASIL. Decreto n. 5.626, de 22 de dezembro de 2005. Regulamenta a Lei no 10.436, de 24 de abril de 2002, que dispõe sobre a Língua Brasileira de Sinais - Libras, e o art. 18 da Lei no 10.098 , de 19 de dezembro de 2000. Brasília, DF, 2005.

BRASIL. Lei n. 12.319, de 01 de setembro de 2010. Regulamenta a profissão de Tradutor e Intérprete da Língua Brasileira de Sinais - LIBRAS. Brasília, DF, 2010.

BRASIL. Lei n. 13.146, de 6 de julho de 2015. Institui a Lei Brasileira de Inclusão das Pessoas com Deficiência (Estatuto da Pessoa com Deficiência). Brasília, DF, 2015.

CANALE, M.; SWAIN, M. Theorical Bases Communicative Approaches to second language teaching and testing. Aplied Linguistics, v. 1, n. 1, 1980.

CAPOVILLA, A. G. S.; CAPOVILLA, F. C. Treino de consciência fonológica e seu impacto em habilidades fonológicas, de leitura e ditado de pré-3 a 2a. série. Ciência Cognitiva: Teoria, Pesquisa e Aplicação, v. 1, n. 2, p. 461-532, 1997.

CHUN, D. M. Discurse Intonation in L2: From theory and research to practice. Benjamins Publishing Company, 2002.

EVANS, V. Cognitive Linguistics: a complete guide. 2. ed. Edinburgh: Edinburgh University Press, 2019.

FELTES, H. P. M. Semântica Cognitiva: ilhas, pontes e teias. Porto Alegre: Edipucrs, 2007.

HURTADO ALBIR, A. Aquisição da competência tradutória: aspectos teóricos e didáticos. In: PAGNO, A.; MAGALHÃES, C.; ALVES, F. (Orgs.). Competência em tradução: cognição e discurso. Belo Horizonte: Editora da UFMG, 2005. p. 19-57. 
JAKOBSON, R. Linguística e comunicação. 22. ed. São Paulo: Cultrix, 1976.

LAKOFF, G. Women, fire, and dangerous things: What categories reveal about the mind. Chicago: The University of Chicago Press, 1987.

MACHADO, F. M. A. Conceito abstratos: escolhas interpretativas de português para Libras. 2. ed. Curitiba: Appris, 2017.

MAGALHÃES, JR., E. Sua Majestade o intérprete: o fascinante mundo da tradução simultânea. São Paulo: Parábola Editorial, 2007.

MORAIS, J. Phonological Awareness: A Bridge Between Language and Literacy. In: SAWYER, D. J.; FOX, B. J. (Eds). Phonological Awareness in Reading: The Evolution of Current Perspectives. Berlin: Springer-Verlag, 1991.p. 31-71.

PEREIRA, M. C. C. Testes em proficiência linguística em língua de sinais: as possibilidades para os intérpretes de Libras. 2008. Dissertação (Mestrado em Linguística Aplicada) - Programa de PósGraduação em Linguística Aplicada, Universidade Vale dos Sinos, São Leopoldo, 2008.

PICCOLOTTO, L.; SOARES, R. M. F. Técnicas de impostação e comunicação oral. São Paulo: Loyola, 1977.

SAPIR, E. Language: An Introduction to the Study of Speech. New York: Harcourt, Brace \& World Inc., 1921. Edição Kindle (e-book).

SAUSSURE, F. Curso de Linguística Geral. São Paulo: Cultrix, 2006.

\section{Sobre os autores}

Flávia Medeiros Álvaro Machado (Orcid iD: https://orcid.org/0000-0003-2075-6713)

Doutora em Letras pela Universidade de Caxias do Sul (UCS/UniRitter); mestra em Letras, Cultura e Regionalidade pela UCS. É professora do Departamento de Línguas e Letras e do Programa de Pós-Graduação em Linguística da Universidade Federal do Espírito Santo (UFES).

Leandro Alves Wanzeler (Orcid iD: https://orcid.org/0000-0003-3758-1075)

Mestrando no Programa de Pós-Graduação em Linguística da Universidade Federal do Espírito Santo (UFES); especialista em Gestão de Políticas Públicas em Gênero e Raça e bacharel em Tradução e Interpretação pela mesma instituição. É professor bilíngue do município de Serra e professor de Deficiência Intelectual e Deficiências Múltiplas do município de Vila Velha.

Rutileia Gusmão Pinheiro (Orcid iD: https://orcid.org/0000-0002-3939-1913)

Mestranda no Programa de Pós-Graduação em Linguística da Universidade Federal do Espírito Santo (UFES); licenciada em História pelo Instituto Batista de Educação de Vitória/ES (IBEV). Técnica pedagógica da Coordenação de Educação Especial do município de Cariacica e professora de séries iniciais do município de Vila Velha.

Recebido em abril de 2021.

Aprovado em julho de 2021. 